\title{
IETS OVER ONS ARMWEZEN.
}

Dit onderwerp door Mr. A. Beaujon in "de Economist" van MaartApril dezes jaars behandeld, behoort tot die welke algemeene belangstelling vinden. $B_{i j}$ ons Armwezen is zeker een zeer groot aantal betrokken, ik bedoel daarmede niet de bedeelden maar de bedeelers, die vele personen die in onze diakonien of armbesturen zitting hebben of gehad hebben, zonder nog van die particulieren wior hart tot liefdadigheid gestemd is, te spreken.

Wanneer men dan in een dergelijk artikel onjuiste voorstellingen of gevolgtrekkingen ontmoet, is het eerder noodig die te bestrijden omdat zulke onjuistheden zoo gemakkelijk bij eene groote menigte ingang of geloof vinden.

Als zoodanig gevoel ik mij gedrongen des schrijvers beweeren te bestrijden, dat we lezen op pag. 247, „dat de kerkelijke besturen bijna voor de helft, de burgerlijke en particuliere voor meer dan de helft, valide personen bedeelen. Immers een persoon, die niet voortdurend maar alleen 's winters, of, zooals het armenverslag het uitdrukt, in den loop van het jaar een of meermalen bedeeling noodig heeft," is zonder eenigen twijfel een valide arbeider, die van zijnen arbeid leeft in de tijdperken, gedurende welken hij van de bedeelingslijsten verdwijnt," en later schrijft de heer $B$. nog ${ }_{n}$ er wordt dientengevolge in tallooze gevallen bedeeling uitgereikt aan arbeidende personen als supplement op onvoldoende loonen."

Deze veronderstelling is ten eenenmale, althans wat den toestand te Amsterdam betreft, onjuist. De tijdelijk (in tegenstelling van doorloopend) bedeelde is geen valide persoon; mannen van eene zwakke gezondheid, die b. v. als schilder of als stukadoor in den zomer nog hun brood kunnen verdienen, komen in den winter, als zij niet als sjouwerlieden b. v. bij de gazfabriek werkzaam kumnen zijn, soms aan de bedeeling.

Maar dezen maken nog de uitzondering uit onder de tijdelijk bedeelden. De hoofden der aldus bedeelde gezinnen zijn niet werklieden, zijn niet mannen, maar vrouwen. Het zijn de weduwen, 
verlaten of ongehuwde vrouwen met kinderen, die zich ò zonder hulp niet kunnen redden of althans den winter niet kunnen doorkomen, terwijl zij in den zomer genoeg schoonmaakhuizen enz. hadden.

Mannen als hoofden van gezinnen bedeeld, zijn in den regel niet valide. Op de 1000 die bedeeld worden, hetzij doorloopend, hetzij tijdelijk, zijn geen 100 mannen hoofden van huisgezinnen (zieke of invalide.) (*)

Dit levert juist naar mijn inzien het moeilijkste vraagstuk der bedeeling. De loonen, voor vrouwenarbeid toegekend, zijn te laag. Hoe daarin verbetering te brengen? Door ze te laten omkomen van gebrek? Door ondersteuning toch bestendigt men de lage loonen.

De heer B., in zijne veronderstelling met valide mannen te doen te hebben wil de bedeelden in groote werkinrichtingen als de Maatschappij van Weldadigheid bijeengaren. Ik zou eer geneigd zijn te zeggen dat de geschiedenis dier Maatschappij ons geleerd heeft, hoe weinig doeltreffend zulke werkinrichtingen zijn. Al ben ik zeer bereid mede te werken om die Maatschappij in stand te houden, omdat zij als uitzondering voor enkele gevallen nuttig kan zijn, geloof ik toch niet dat 't geraden zou zijn meerdere dergelijke opterichten.

Maar 't is een tweede vraag of men, wat als door de heer B. voor valide mannen wenschelijk geacht wordt, ook voor vrouwen zou willen opgericht zien. Voor naaien, breien en wasschen, - wel de drie voornaamste takken van vrouwelijken huislijken arbeid groote werkinrichtingen te maken, zou zeker 't doel voorbijstreven.

(*) Ik spreek alleen van den toestand te Amsterdam, omdat ik dien eenigszins meen to kunnen beoordeelen. Maar wat voor Amsterdam geldt zal ook voor andere groote gemeenten waar zijn, omdat de omstandigheden daar weinig zullen verschillen. Zoo leest men in het verslag van het Burgerlijk Armbestunr te Amsterdam over 1876 op pag. 9 (Bijlage VII van het Gemeenteverslag) : "De vermeerdering ligt "derhalve nagenoeg uitsluitend in de omstandigbeid, dat zich zoo vele hulpbe"hoevende weduwen hebben aangemeld, die krachtige ondersteuniug behoefden."

In dat over 1878 (pag. 9) Bijlage IX van het Geneenteverslag: "De gehuwde "partijen voorkomende onder de doorloopend bedeelden zijn zonder uitzondering of mafgeleerde, of voortdureod kranken, of verminkten; geen valide gehuwde man "geniet doorloopend geldelijke bedeeling, en alleen bij groote witzondering is is "WNKELE GEVALLN bij dringenden nood aan eenigen hunner monenteel geldelijke "hulp verstrekt; ook de alleenstaande personeo, wasraan wekelijksche onderstand in geld wordt gegeven, zịn meest allen hoogbejaarden, ongeneeslijke zieken en minvalide." 
Men heeft immers machines uitgevonden welke dien arbeid uitstekend verrichten, on in dergelijke werkinrichtingen zou men die machines spoedig door stoom gaan drijven. Hoe de moeders van huisgezinnen door de kinderen aan huis gebonden 't best te helpen, ziedaar naar mijn oordeel wel de belangrijkste en moeilijkste vraag bij armenzorg. Voor hulp aan mannen zie ik minder bezwaar. Zijn zij niet ziek of invalide, help hen dan niet; dat zal in den regel wel 't beste zijn.

Ten slotte nog een woord over onderstand in geld, waartegen Mr. B. te velde trekt. $\left(^{*}\right)$ Geld is nu eenmaal het algemeene ruilmiddel, en or [zijn ook nog vele andere dingen, dan kleeren, levensmiddelen, brand enz. noodig. Misschien is ééne zák nog noodiger, ja zelfs dan voedsel, te weten: eene woning. De hurisheer is nog onverbiddelijker dan de maag. Hij is alleen in geld té voldoen en de meeste onderstand aan armen strekt dan ook voor de huishuur. Daarvoor legt hij het geld zorgvuldig op zij.

De uitspraak van den heer B.: ${ }_{n}$ de arme is geneigd misbruik ; van zijin geld te maken. Te ontkennen is het niet. Hooveel van "het geld gaat naar het snoeptafeltje en hoeveel aan drank?" Die nitspraak vloeit voort uit dezelfde onjuiste veronderstelling dat de valide werkman bedeeld wordt, dat zijn loon door onderstand wordt aangevuld. Onder de werklieden ja zijn er helaas velen die misbruik van hun geld maken, die hun loon verbrassen, maar onder de eigenlijke armen niet.

Laat ons resumeeren. De veronderstelling van den heer B., dat mannelijke valide armen bedeeld worden is mijns inziens onjuist. Het middel door hem aangeprezen: stichting van groote werkinrichtingen is dus niet toepasselijk, want het is voor vrouwen met hoisgezinnen belast onmogelijk te achten of zou geheel verkeerd werken.

Ansterdam.

N. J. Den TeX.

Awrwookd. Gaarne maak ik gebruik van de mij door de Redactie van ${ }_{n}$ de Economist" aangeboden gelegenheid, om in ditzelfde No. to antwoorden op het artikel van den heer $N$. J. den Tex, waarin sommige mijner beweringen omtrent ons armwezen in het No. van Maart-April jl. onjuist worden geoordeeld.

$\left(^{*}\right)$ Reeds zoo goed bestreden in de Nieuwe Rotterdamsche Courant van 6,7 en 9 Mei jl. 
10. De vraag der winterbedeeling en van haar verband met de arbeidsloonen. Onjuist is het, volgens den heer $\mathrm{D}$. T., dat zij, die alléén 's winters bedeeling ontvangen, valíde zijn. 't Zijn, althans te Amsterdam, bijna allen rrouwen, moeders van huisgezinnen, die 's zomers met schoonmaken enz. den kost verdienen. Vooreerst zij opgemerkt dat de geëerde schrijver alléén van Amsterdam spreekt en ik van Nederland sprak, zoodat, strict genomen, zijne bestrijding niet op mijne bewering terugslaat. In kleine steden en ten platten lande ziet het er geheel anders uit; die dáár 's' winters armlastig worden, zijn denkelijk meerendeels personen die tot na afloop van den oogst met veld- en dergelijken arbeid den kost verdienen; mannen of vrouwen, dat is ten deze onverschillig. Hoe belangrijk, juist in plattelandsgemeenten, het aantal dezer personen is, kan blijken uit onderstaand staatje, getrokken uit tabel 4 der bijlagen bij de statistiek van 't armwezen over 1875. Kerkelijke besturen voor huiszittende armen (diaconiën dus) bedeelden in 1875:

\begin{tabular}{|c|c|c|c|c|c|}
\hline \multirow{2}{*}{ IN GEMEENTEN } & \multirow{2}{*}{ VAN } & \multicolumn{2}{|c|}{$\begin{array}{l}\text { Gedurende het geheele } \\
\text { jaar. }\end{array}$} & \multicolumn{2}{|c|}{$\begin{array}{l}\text { Fens of meermalen of } \\
\text { alleen 's winters. }\end{array}$} \\
\hline & & $\begin{array}{l}\text { Hoofden van } \\
\text { huisgetinnen. }\end{array}$ & $\begin{array}{l}\text { Lenl. perm } \\
\text { sonen. }\end{array}$ & $\begin{array}{l}\text { Hoofden van } \\
\text { gezinnen. }\end{array}$ & $\begin{array}{c}\text { Enkele } \\
\text { persohóh. }\end{array}$ \\
\hline 1-3000 zielen & . & 6443 & 4953 & 10483 & 3442 \\
\hline $3-10,000$ zielen & . & 8281 & 5872 & 11543 & 4388 \\
\hline $10-20,000$ zielen. & . & 2886 & 1921 & 2875 & 1067 \\
\hline
\end{tabular}

Het is wel hoogst onwaarschijnlijk, dat de ca. 22,000 hoofden van huisgezinnen die in gemeenten beneden 10,000 zielen 's winters enkel door de diaconien worden ondersteund on alsdan den armenlast verdubbelen, alle of meerendeels schoonmaaksters zijn. Ik betwijfel of men in vele dier gemeenten weet wat eene schoonmaakster is; ieder houdt op 't platteland en in de dorpen doorgaans zijn eigen woning schoon, en de vrouwen doen het ligtere werk te velde, als zij iets verdienen moeten. Dat work ontbreekt 's winters, ergo.

Maar dat is van ondergeschikt belang. De hoofdzaak is de quaestie der validiteit. Wat noemt de heer D. T. "valide"? Onjuist is het volgens hem, dat de alléén 's winters bedeelden meerendeels valide zijn. Het zijn niet werklieden maar vrouwen, schoonmaaksters enz., die 's zomers als zoodanig den kost verdienen. Derhalve - ik vind hierop geen anderen uitweg - zulke vrouwen zijn volgens hem geen werklieden en ni-t valide. Wanneer men de tallooze schoonmaaksters in onze groote steden ziet zwoegen, 's zomers 
vooral, maar toch ook nog al eens in den winter, zou men geneigd zijn dit anders in te zien.

Welligt bestaat er bij sommige armbesturen eene, mij onbekende, gevestigde interpretatie van 't woord valide, die vrouwen uitsluit. Ik zou, behoudens voorlichting hieromtrent, als valide willen qualificeren: alle personen, zonder onderscheid van sekso of leeftijd, die door eenige soort van arbeid in 't onderhoud van hun persoon of hun gezin voorzien kunnen, gedurende een saizoen dat zich tot dien arbeid leent. Of die personen nu mannen of vrouwen, vlasplukkers, matrozen ter vischvangst, schoonmaaksters of iets anders zijn, is voor 't punt in quaestie onverschillig. Z Zij kunnen arbeiden, zijn 't halve jaar dien ten gevolge niet armlastig, en zijn derhalve $\mathrm{m}$. $\mathbf{i}$. aan te merken als valide arbeiders. Hun arbeid wordt echter onvoldoende betaald om voor den winter op te sparen, of wèl zij zijn tot opsparen te zorgeloos en rekenen voor den winter op de armenkas. De hun 's winters verstrekte bedeeling is derhalve wel degelijk, ten deele een uitvloeisel hunner zorgeloosheid, maar in hoofdzaak datgene waarin ik het ernstigste gebrek van ons armwezen blijf zien: onderstand als supplement op te lage loonen, die de onvoldoendheid der loonen slechts bestendigen kan. Te lage loonen en zorgeloosheid, ziedaar de twee drijfraderen die het vraagstuk der winterbedeeling steeds gaande houden.

Hoe nu die raderen te verlammen, en speciaal: hoe de loonen hooger te krijgen? De heer D. T. laat die rraag eenvoudig open, en constateert, gelijk .talloozen vóór hem, dat zij het moeijelijkste vraagstuk der bedeeling is. Hierover zullen allen 't wel ééns zijn, doch ik kan niet inzien dat dit ons veel verder brengt. Ik waagde het in mijn bestreden artikel, een middel aan de hand te doen, en ontveinsde mij daarbij, gelijk uit het artikel voldoende zal zijn gebleken, de daaraan verbonden bezwaren in geenen deele $\left(^{*}\right)$. Ik vroeg mij in hoofdzaak af, niet: hoe de menschen 's winters te helpen, maar: hoe in de te lage loonen en in de zorgeloosheid, die hen 's winters hulpbehoevend maken, verbetering te brengen. Dit kan m. i. nooit geschieden door bedeeling aan huis, in welken vorm dan ook. Er dient een maatregel

(*) Die bezwaren, door de N. R. Ct in bare door Schr. aangehaalde nrs. uiteengezet, besprak ik overigens nog in gemeld dagblad, no. van 7 Junij 11 ., Iste blad, waarnaar ik meen te mogen verwijzen, daar tot berhaalde niteenzetting tijd en ruimte hier ontbreken. 
te worden beraamd of althans gezocht, die de conditiën der arbeidsmarkt wijzigt in de takken van bestaan, die 's winters verdorren. En hoe dit te bewerkstelligen zonder een deel van 't aanbod tijdelijk, en een kleiner deel voor goed, aan de vrije markt te onttrekken, zie ik niet in. Blijkt mijn denkbeeld totaal onuitvoerbaar, dan ziet het er m. i slecht uit met de vooruitzigten der winterbedeeling. Blijkt het vatbaar voor wijziging, verbetering, partiële en allengs meer uitgebreide toepassing, zooveel te beter. In elk geval meen ik vooruitgang te hebben gezocht op den éénigen weg, waarop zij welligt ééns kan worden gevonden: Bestrijding van de oorzaken zelve der winterbedeeling. Bedeelen als voorheen helpt ons, ook blijkens de ondervinding, niet verder.

20. De quaestie van bedeeling in geld of in natura. De mate, waarin de armen met geld kunnen worden vertrouwd, is niet onder eijfers te brengen. "Onder de eigenlijke armen" zijn er volgens den heer $D$. T. geen, die misbruik van hun geld maken. De $N$. R. Ct. is van een ander gevoelen; zij zegt (in haar no. van 22 Junij nogmaals mijn artikel besprekende): ${ }$ Niemand kan het "feit loochenen dat vooral onder de minder ontwikkelden van geld "groot misbruik wordt gemaakt; zeker is het ook, dat de zucht "tot verkwisting die zich onder hen openbaart, aangewakkerd "wordt door allen die gedachteloos en zonder onderzoek geven en ${ }_{n}$ nog eens geven." Hier is derhalve wel degelijk sprake van verkwisting en misbruik onder lieden, wien gegeven wordt, dus armen. $\mathrm{Nu}$ is toch misbruik zeker gemakkelijker waar geld, dan waar roedsel of kleeding wordt verstrekt: Maar de voornaamste reden waarom ik aan dit laatste de voorkeur gaf, is deze: het getuigt van toewijding en onderzoek; geld daarentegen kan een ieder geven, ook "gedachteloos en zonder onderzoek" zooals de $N$. $R$. C $t$. zegt. Geld is en blijft gevaarlijk; méér of minder naarmate de bedeelde min of meer eerlijk is. De heer D. T. is overigens, blijkens het door hem geschrevene, van oordeel dat invalide bedeelden (volgens hem de éénige " misbruiken, en zoodanig misbruik alléén van valide werklieden (volgens schr. geen armen) te vreezen is. Het zou hoogst belangrijk zijn, de reden van dit verschijnsel, door schr. ongetwijfeld in zijne omgeving waargenomen, te kennen. Voorshands schijnt het vreemd; worden de lieden door 't bekomen van physieke gebreken van morele gebreken vrij ?

$$
\text { 's Hage. }
$$

A. Beaujon.

Econ. 1879. 